\title{
PENGARUH GAYA KEPEMIMPINAN DEMOKRATIS, MOTIVASI INTRINSIK DAN DISIPLIN KERJA TERHADAP KINERJA KARYAWAN PT PANGANSARI UTAMA FOOD INDUSTRY
}

\author{
Elsa Nopitasari \\ Herry Krisnandy \\ Email: elsanopitasari@gmail.com, hery_krisnandi@yahoo.co.id \\ Program Studi Manajemen Fakultas Ekonomi \\ Universitas Nasional
}

\begin{abstract}
ABSTRAK
Penelitian ini bertujuan untuk menguji dan menganalisis pengaruh gaya kepemimpinan demokratis, motivasi intrinsik dan disiplin kerja terhadap kinerja karyawan PT Pangansari Utama Food Industry, Jakarta Timur. Populasi yang digunakan dalam penelitian ini adalah seluruh karyawan PT Pangansari Utama Food Industry, Jakarta Timur. Dengan menggunakan rumus Slovin, jumlah sampel yang digunakan dalam penelitian ini adalah 100 responden. Penelitian ini menggunakan metode regresi linear berganda yang diolah dengan SPSS 17.0. Hasil penelitian menunjukkan bahwa gaya kepemimpinan demokratis, motivasi intrinsik dan disiplin kerja secara parsial berpengaruh positif dan signifikan terhadap kinerja karyawan PT Pangansari Utama Food Industry, Jakarta Timur.
\end{abstract}

Kata kunci: Gaya kepemimpinan demokratis, motivasi intrinsik, disiplin kerja, kinerja karyawan

\begin{abstract}
This study aims to test and analyze the effect of democratic leadership style, intrinsic motivation and job discipline on employee performance of PT Pangansari Utama Food Industry, East Jakarta. Population used in this study was all employees of PT Pangansari Utama Food Industry, East Jakarta. By used Slovin formula, the amount of samples used in this study was 100 respondents. This study used multiple linear regression that processed with SPSS 17.0. Results of the study showed that democratic leadership style, intrinsic motivation and job discipline partially has positive and significance effect partially on the employee performance of PT Pangansari Utama Food Industry, East Jakarta.
\end{abstract}

Keywords: Democratic leadership style, intrinsic motivation, job discipline, employee performance

\section{PENDAHULUAN}

Sumber daya manusia merupakan salah satu unsur yang mempunyai peran penting dalam suatu organisasi karena kesuksesan suatu organisasi ditentukan oleh peran yang dijalankan oleh orang-orang yang ada di dalam organisasi itu sendiri. Kegiatan organisasi tidak akan berjalan tanpa adanya keterlibatan manusia. Organisasi akan berhasil mencapai tujuannya apabila sumber daya manusianya dikelola dengan baik. Semakin baik pengelolaan sumber daya manusia dalam suatu organisasi, maka semakin tinggi tingkat keberhasilan pencapaian tujuan perusahaan. 
Kinerja manajemen dan karyawan dalam suatu organisasi dapat diukur dari pencapaian target yang telah ditetapkan oleh manajemen. Penjualan Heat \& Eat yang diproduksi oleh PT Pangansari Utama Food Industry pada tahun 2015 dan 2016 sudah cukup baik, tetapi belum berhasil mencapai target penjualan yang telah ditetapkan. Oleh karena itu, perusahaan perlu meningkatkan kinerja karyawannya agar dapat mencapai target penjualan di masa yang akan datang.

Kinerja karyawan dapat dipengaruhi oleh berbagai macam faktor. Salah satu faktor yang dapat mempengaruhi kinerja karyawan dalam suatu perusahaan adalah gaya kepemimpinan yang diterapkan di perusahaan tersebut. Hal ini sesuai dengan hasil penelitian yang dilakukan oleh Mardiana (2014) yang menunjukkan bahwa gaya kepemimpinan demokratis berpengaruh positif dan signifikan terhadap kinerja karyawan. Hal tersebut dikarenakan gaya kepemimpinan demokratis memberikan kesempatan kepada karyawan untuk berpartisipasi dalam setiap kegiatan dan pengambilan keputusan sesuai dengan jabatan kemampuan dan keterampilannya. Hal ini membuat karyawan merasa dilibatkan oleh pimpinan, sehingga karyawan tersebut terdorong untuk melaksanakan tugas dan pekerjaannya dengan baik. Akibatnya, karyawan tersebut akan mencapai kinerja yang baik.

Kinerja karyawan juga dapat dipengaruhi oleh motivasi intrinsik. Hasil penelitian yang dilakukan oleh Suwarno (2014) menunjukkan bahwa motivasi intrinsik berpengaruh positif dan signifikan terhadap kinerja karyawan. Hal tersebut dikarenakan semakin kuat motivasi intrinsik di dalam diri seorang karyawan, maka semakin kuat perilaku karyawan tersebut diarahkan untuk mencapai tujuan, sehingga semakin tinggi kinerja yang dihasilkannya.

Selain gaya kepemimpinan demokratis dan motivasi intrinsik, disiplin kerja juga dapat mempengaruhi kinerja karyawan. Hal ini sesuai dengan hasil penelitian yang dilakukan oleh Yudiningsih, dkk. (2016) yang menunjukkan bahwa disiplin kerja berpengaruh positif dan signifikan terhadap kinerja karyawan. Hal tersebut dikarenakan semakin tinggi disiplin kerja seorang karyawan, maka semakin tinggi rasa tanggung jawab yang ada di dalam diri karyawan tersebut terhadap tugas-tugas yang dibebankan kepadanya, sehingga semakin tinggi pula kinerja dan prestasi kerja yang dicapai oleh karyawan tersebut.

Berdasarkan latar belakang tersebut, perlu dilakukan penelitian untuk menguji dan menganalisis pengaruh gaya kepemimpinan demokratis, motivasi intrinsik dan disiplin kerja terhadap kinerja karyawan PT Pangansari Utama Food Industry, Jakarta Timur. 


\section{TINJAUAN PUSTAKA}

\section{Gaya Kepemimpinan}

Menurut Rivai (2011:64) gaya kepemimpinan adalah sekumpulan ciri yang digunakan pemimpin untuk mempengaruhi bawahan agar sasaran organisasi tercapai. Menurut Rivai (2011:122) ada tiga macam gaya kepemimpinan yang dapat mempengaruhi bawahan agar sasaran organisasi tercapai, yaitu gaya kepemimpinan otoriter, gaya kepemimpinan bebas dan gaya kepemimpinan demokratis.

\section{Gaya Kepemimpinan Demokratis}

Robbins (2006:167) menyatakan bahwa gaya kepemimpinan demokratis menggambarkan pemimpin yang cenderung melibatkan karyawan dalam mengambil keputusan, mendelegasikan wewenang, mendorong partisipasi dalam memutuskan metode dan sasaran kerja, dan menggunakan umpan balik sebagai peluang untuk melatih karyawan. Menurut Rivai (2011:56), tipe kepemimpinan ini menempatkan manusia sebagai faktor utama dan yang terpenting dalam setiap kelompok atau organisasi.

\section{Indikator Gaya Kepemimpinan Demokratis}

Menurut Sutarto (2006:75), indikator kepemimpinan demokratis antara lain sebagai berikut.

1. Wewenang pimpinan tidak bersifat mutlak

2. Keputusan dibuat bersama antara pimpinan dan bawahan

3. Kebijakan dibuat bersama antara pimpinan dan bawahan

4. Komunikasi berlangsung timbal balik

5. Pengawasan dilakukan secara wajar

6. Banyak kesempatan bagi bawahan untuk menyampaikan saran, pertimbangan dan pendapat.

7. Tugas-tugas kepada bawahan diberikan dengan menggunakan permintaan dan berdasarkan pada instruksi.

8. Tanggung jawab ditanggung bersama oleh pimpinan dan bawahan

\section{Motivasi Intrinsik}

Motivasi intrinsik merupakan dorongan atau kehendak yang kuat yang berasal dari dalam diri seseorang (Gunarsa, 2008:50). Menurut Sardiman (2007:89) dalam Suwarno 
(2014), motivasi intrinsik adalah motif-motif yang aktivasinya tidak perlu dirangsang dari luar, karena sudah ada dorongan untuk melakukan sesuatu di dalam diri setiap individu. Menurut Robbins (2006:208), motivasi intrinsik diukur dengan prestasi, penghargaan, tanggung jawab, dan pengembangan diri.

\section{Indikator Motivasi Intrinsik}

Menurut Robbins (2006:208), motivasi intrinsik memiliki indikator-indikator sebagai berikut.

1. Prestasi

2. Penghargaan

3. Tanggung jawab

4. Pengembangan diri

\section{Disiplin Kerja}

Menurut Hasibuan (2012:193), kedisiplinan adalah kesadaran dan kesediaan seseorang menaati semua peraturan perusahaan dan norma-norma sosial yang berlaku. Disiplin kerja adalah suatu alat yang dapat digunakan oleh manajer untuk berkomunikasi dengan karyawannya agar mereka bersedia mengubah suatu perilaku sebagai suatu upaya untuk meningkatkan kesadaran dan kesediaan dalam mematuhi semua peraturan perusahaan dan norma-norma sosial yang berlaku (Rivai, 2011). Mangkunegara (2011:824) mendefinisikan disiplin kerja sebagai suatu alat yang digunakan para manajer untuk berkomunikasi dengan karyawannya agar mereka bersedia untuk mengubah suatu perilaku sebagai suatu upaya untuk meningkatkan kesadaran dan kesediaan seseorang mematuhi semua peraturan perusahaan dan norma-norma sosial yang berlaku.

\section{Macam-Macam Disiplin Kerja}

Menurut Mangkunegara (2011:129), ada dua bentuk disiplin kerja, yaitu sebagai berikut.

1. Disiplin preventif

Disiplin adalah suatu upaya menggerakan karyawan untuk mengikuti dan mematuhi peraturan kerja dan aturan-aturan yang telah digariskan oleh perusahaan. 
2. Disiplin korektif

Disiplin korektif adalah suatu upaya menggerakan karyawan dalam penyatuan suatu peraturan dan mengarahkan untuk tetap mematuhi peraturan sesuai dengan pedoman yang berlaku pada perusahaan.

\section{Indikator Disiplin Kerja}

Menurut Hasibuan (2012:194), indikator disiplin kerja antara lain sebagai berikut.

1. Mematuhi semua peraturan

2. Tanggung jawab dalam pekerjaan dan tugas

3. Tingkat absensi

4. Waskat (pengawasan melekat)

5. Sanksi hukuman

\section{Kinerja}

Menurut Wibowo (2011:7), kinerja adalah hal-hal yang berkaitan dengan pelaksanaan pekerjaan dan hasil yang dicapai dari pekerjaan tersebut. Menurut Mangkunegara (2011:67), kinerja adalah hasil kerja secara kualitas dan kuantitas yang dicapai oleh seorang karyawan dalam melaksanakan tugasnya sesuai dengan tanggung jawab yang diberikan kepadanya. Adapun Hasibuan (2012:94) mendefinisikan kinerja sebagai suatu hasil kerja yang dicapai seseorang dalam melaksanakan tugas-tugas yang dibebankan kepadanya yang didasarkan atas kecakapan, pengalaman dan kesungguhan serta waktu.

\section{Tujuan Penilaian Kinerja}

Menurut Sedarmayanti (2011:262), tujuan penilaian kinerja antara lain sebagai berikut.

1. Meningkatkan kinerja karyawan dengan cara membantu mereka agar menyadari dan menggunakan seluruh potensi mereka dalam mewujudkan tujuan organisasi.

2. Memberikan informasi kepada karyawan dan pimpinan sebagai dasar untuk mengambil keputusan yang berkaitan dengan pekerjaan.

\section{Indikator Kinerja}

Menurut Robbins (2006:260), kinerja karyawan memiliki enam indikator, yaitu sebagai berikut. 
1. Kualitas kerja

2. Kuantitas kerja

3. Tanggung jawab

4. Ketepatan waktu

5. Efektivitas

6. Kemandirian

\section{Keterkaitan Antarvariabel Penelitian}

\section{Keterkaitan antara Gaya Kepemimpinan Demokratis dan Kinerja Karyawan}

Perilaku pemimpin yang demokratis cenderung mendorong para karyawannya untuk menumbuhkan dan mengembangkan daya inovasi dan kreativitasnya, sehingga dapat meningkatkan kinerja karyawan di bawah pimpinannya (Siagian, 2010). Menurut Rivai (2011), gaya kepemimpinan demokratis ditandai dengan adanya suatu struktur yang pengembangannya menggunakan pendekatan pengambilan keputusan yang kooperatif. Hal ini membuat karyawan merasa dilibatkan oleh pimpinan, sehingga karyawan tersebut terdorong untuk melaksanakan tugas dan pekerjaannya dengan baik. Akibatnya, karyawan tersebut akan mencapai kinerja yang baik. Hal tersebut menunjukkan bahwa gaya kepemimpinan demokratis dapat berpengaruh positif terhadap kinerja karyawan. Hal ini sesuai dengan hasil penelitian yang dilakukan oleh Mardiana (2014) yang menunjukkan bahwa gaya kepemimpinan demokratis berpengaruh positif dan signifikan terhadap kinerja karyawan.

H1: Gaya kepemimpinan demokratis berpengaruh positif dan signifikan terhadap kinerja karyawan PT Pangansari Utama Food Industry, Jakarta Timur.

\section{Keterkaitan antara Motivasi Intrinsik dan Kinerja Karyawan}

Hasil penelitian yang dilakukan oleh Suwarno (2014) menunjukkan bahwa motivasi intrinsik berpengaruh positif dan signifikan terhadap kinerja karyawan. Motivasi intrinsik yang dimaksud disini adalah motivasi karyawan untuk melaksanakan tugas dan pekerjaannya dengan baik. Semakin kuat motivasi intrinsik di dalam diri seorang karyawan, maka semakin kuat pula keinginan karyawan tersebut untuk melaksanakan tugas dan pekerjaannya dengan baik, sehingga semakin terdorong perilaku karyawan tersebut untuk diarahkan sesuai dengan standar kinerja dan tujuan yang telah ditetapkan oleh perusahaan. Hal tersebut pada akhirnya akan meningkatkan kinerja karyawan tersebut.

H2: Motivasi intrinsik berpengaruh positif dan signifikan terhadap kinerja karyawan PT Pangansari Utama Food Industry, Jakarta Timur. 


\section{Keterkaitan antara Disiplin Kerja dan Kinerja Karyawan}

Hasil penelitian yang dilakukan oleh Yudiningsih, dkk., (2016) menunjukkan bahwa disiplin kerja berpengaruh positif dan signifikan terhadap kinerja karyawan. Menurut Robbins (2006), disiplin kerja yang tinggi diindikasikan dengan adanya rasa tanggung jawab yang tinggi dalam diri karyawan terhadap tugas-tugas yang dibebankan kepadanya. Artinya, semakin tinggi tingkat disiplin kerja seorang karyawan, maka semakin tinggi pula rasa tanggung jawab di dalam diri karyawan tersebut terhadap tugas-tugas yang dibebankan kepadanya, sehingga semakin besar upaya yang dilakukan oleh karyawan tersebut untuk melaksanakan tugas dan pekerjaannya dengan baik. Hal ini pada akhirnya akan meningkatkan kinerja karyawan tersebut.

H3: Disiplin kerja berpengaruh positif dan signifikan terhadap kinerja karyawan PT Pangansari Utama Food Industry, Jakarta Timur.

\section{Kerangka Analisis}

Berikut ini merupakan kerangka analisis yang digunakan dalam penelitian ini.

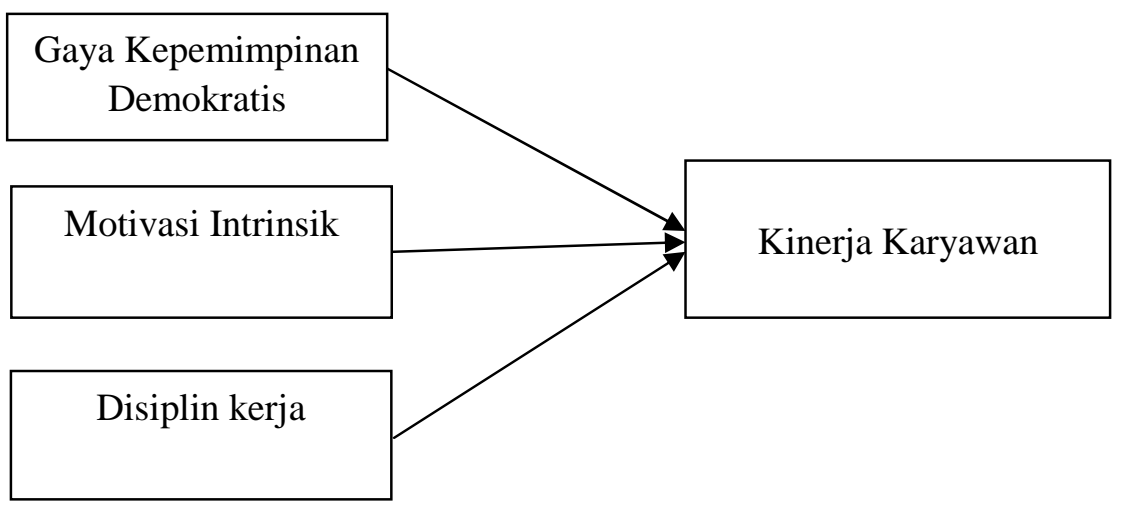

Gambar 1. Kerangka Analisis

\section{METODE PENELITIAN}

\section{Sumber dan Jenis Data}

Data yang digunakan dalam penelitian ini adalah data primer yang bersumber dari perusahaan dan penyebaran kuesioner kepada responden.

\section{Populasi dan Sampel}

Populasi yang digunakan dalam penelitian ini adalah seluruh karyawan PT Pangansari Utama Food Industry yang berjumlah 133 karyawan. Jumlah sampel ditentukan menggunakan rumus Slovin berikut. 


$$
\mathrm{n}=\frac{\mathrm{N}}{1+\mathrm{Ne}^{2}}
$$

Keterangan:

$$
\begin{aligned}
\mathrm{n} & =\text { Ukuran sampel } \\
\mathrm{N} & =\text { Ukuran populasi } \\
\mathrm{e} & =\text { Batas toleransi kesalahan }
\end{aligned}
$$

Berdasarkan rumus Slovin di atas, jumlah sampel yang digunakan dalam penelitian adalah 100 responden.

\section{Definisi Operasional Variabel}

\begin{tabular}{|c|c|c|c|}
\hline No & Variabel & Definisi Operasional & Indikator \\
\hline 1 & Kinerja karyawan & $\begin{array}{l}\text { Hasil yang dicapai dari suatu } \\
\text { pekerjaan. }\end{array}$ & $\begin{array}{l}\text { 1. Kualitas kerja } \\
\text { 2. Kuantitas kerja } \\
\text { 3. Efektivitas } \\
\text { 4. Kemandirian } \\
\text { (Sumber: Robbins, 2006:260) }\end{array}$ \\
\hline 2 & $\begin{array}{l}\text { Gaya } \\
\text { kepemimpinan } \\
\text { demokratis }\end{array}$ & $\begin{array}{l}\text { Gaya kepemimpinan yang } \\
\text { cenderung } \\
\text { karyawan dalam pengambilan } \\
\text { keputusan. }\end{array}$ & $\begin{array}{l}\text { 1. Wewenang pimpinan tidak } \\
\text { mutlak } \\
\text { 2. Keputusan dibuat bersama } \\
\text { 3. Tanggung jawab dipikul } \\
\text { bersama } \\
\text { 4. Pengawasan dilakukan } \\
\text { secara wajar } \\
\text { (Sumber: Sutarto, 2006:75) }\end{array}$ \\
\hline 3 & Motivasi intrinsik & $\begin{array}{l}\text { Dorongan yang kuat di dalam } \\
\text { diri karyawan untuk } \\
\text { melaksanakan tugas dan } \\
\text { pekerjaan yang dibebankan } \\
\text { kepadanya. }\end{array}$ & $\begin{array}{l}\text { 1. Prestasi } \\
\text { 2. Penghargaan } \\
\text { 3. Tanggung jawab } \\
\text { 4. Pengembangan diri } \\
\text { (Sumber: Robbins, 2006:208) }\end{array}$ \\
\hline 4 & Disiplin kerja & $\begin{array}{l}\text { Kesadaran dan } \\
\text { karyawan untuk mesediaan } \\
\text { peraturan dan norma-norma } \\
\text { yang berlaku di dalam suatu } \\
\text { perusahaan. }\end{array}$ & $\begin{array}{l}\text { 1. Mematuhi peraturan } \\
\text { 2. Tanggung jawab dalam } \\
\text { pekerjaan } \\
\text { 3. Tingkat Absensi } \\
\text { 4. Sanksi hukuman } \\
\text { (Sumber: Hasibuan, 2012:194) }\end{array}$ \\
\hline
\end{tabular}

Berikut ini merupakan definisi operasional variabel yang digunakan dalam penelitian ini.

Tabel 1. Definisi Operasional Variabel 


\section{Metode Analisis}

Metode analisis yang digunakan dalam penelitian ini adalah regresi linear berganda. Analisis ini digunakan untuk menganalisis pengaruh gaya kepemimpinan demokratis, motivasi intrinsik dan disiplin kerja terhadap kinerja karyawan.

\section{HASIL PENELITIAN DAN PEMBAHASAN}

\section{Uji Instrumen}

\section{Uji Validitas}

Berdasarkan hasil uji validitas, semua butir pertanyaan dari setiap variabel bernilai valid karena memiliki $r_{\text {hitung }}$ yang lebih besar daripada $r_{\text {tabel }}(0,194)$.

\section{Uji Reliabilitas}

Berikut ini merupakan tabel hasil uji reliabilitas.

Tabel 2. Hasil Uji Reliabilitas

\begin{tabular}{|l|c|c|c|}
\hline \multicolumn{1}{|c|}{ Variabel } & $\begin{array}{c}\text { Cronbach } \\
\text { Alpha }\end{array}$ & Batasan & Keterangan \\
\hline Gaya Kepemimpinan Demokratis & 0,769 & 0,7 & Reliabel \\
\hline Motivasi Intrinsik & 0,736 & 0,7 & Reliabel \\
\hline Disiplin Kerja & 0,788 & 0,7 & Reliabel \\
\hline Kinerja Karyawan & 0,707 & 0,7 & Reliabel \\
\hline
\end{tabular}

(Sumber: Data diolah, 2016)

Berdasarkan tabel di atas, dapat diketahui bahwa nilai Cronbach Alpha dari setiap variabel berada di atas 0,7 , sehingga sehingga semua konsep pengukur masing-masing variabel dari kuesioner bersifat reliabel.

\section{Uji Asumsi Klasik}

\section{Uji Normalitas}

Berikut ini merupakan tabel hasil uji normalitas.

Tabel 3. Hasil Uji Normalitas

\begin{tabular}{|l|c|}
\hline & $\begin{array}{c}\text { Unstandardized } \\
\text { Residual }\end{array}$ \\
\hline Asymp. Sig. (2-tailed) & 0,639 \\
\hline (Sumber: Data diolah, 2016)
\end{tabular}

Berdasarkan tabel di atas, dapat diketahui bahwa Asymp.Sig.(2-tailed) sebesar 0,639 > 0,05, sehingga data berdistribusi normal. 


\section{Uji Multikolinearitas}

Berikut ini merupakan tabel hasil uji multikolinearitas.

Tabel 4. Hasil Uji Multikolinearitas

\begin{tabular}{|l|r|c|}
\hline \multirow{2}{*}{ Variabel } & \multicolumn{2}{|c|}{ Collinearity Statistics } \\
\cline { 2 - 3 } & Tolerance & \multicolumn{1}{c|}{ VIF } \\
\hline Gaya Kepemimpinan Demokratis & 0,803 & 1,245 \\
Motivasi Intrinsik & 0,361 & 2,767 \\
Disiplin Kerja & 0,335 & 2,981 \\
\hline
\end{tabular}

(Sumber: Data diolah, 2016)

Berdasarkan tabel di atas, dapat diketahui bahwa setiap variabel mempunyai nilai tolerance $>0,1$ dan nilai $\mathrm{VIF}<10$, sehingga dapat disimpulkan bahwa tidak terjadi masalah multikolinearitas dalam model persamaan regresi ini.

\section{Uji Autokorelasi}

Berdasarkan hasil uji autokorelasi, diperoleh Durbin-Watson sebesar 1,760. DurbinWatson tabel pada tingkat signifikansi 5\% dengan jumlah sampel $100(n=100)$ dan jumlah variabel bebas $3(\mathrm{k}=3)$ memiliki nilai $\mathrm{dL}=1,613$ dan $\mathrm{dU}=1,736$. Hal tersebut menunjukkan bahwa model yang digunakan dalam penelitian ini memenuhi kriteria $\mathrm{dU}<\mathrm{DW}<4-\mathrm{dU}$ $(1,736<1,760<2,264)$, sehingga tidak ada autokorelasi dalam model regresi ini.

\section{Uji Heteroskedastisitas}

Berikut ini merupakan scatterplot hasil uji heteroskedastisitas.

Scatterplot

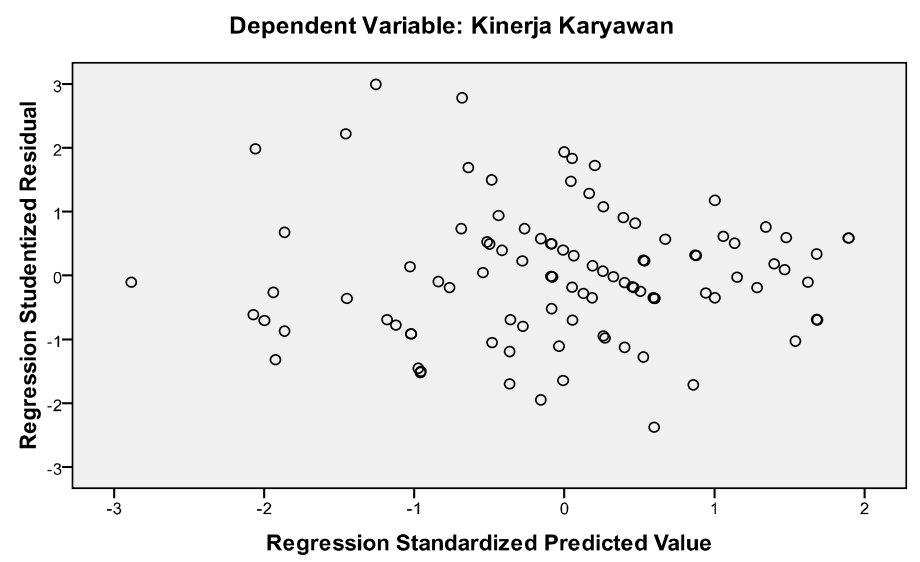

(Sumber: Data diolah, 2016)

\section{Gambar 2. Scatterplot Hasil Uji Heteroskedastisitas}


Berdasarkan gambar di atas, titik-titik menyebar di atas dan di bawah angka 0 pada sumbu Y, sehingga tidak terjadi masalah heteroskedastisitas pada model regresi ini.

\section{Analisis Regresi Linear Berganda}

Berikut ini merupakan tabel hasil uji regresi linear berganda.

Tabel 5. Hasil Analisis Regresi Linear Berganda

\begin{tabular}{|l|r|r|r|r|r|}
\hline \multirow{2}{*}{ Variabel } & \multicolumn{2}{|c|}{$\begin{array}{c}\text { Unstandardized } \\
\text { Coefficients }\end{array}$} & $\begin{array}{l}\text { Standardized } \\
\text { Coefficients }\end{array}$ & \multirow{2}{*}{ t } & \multicolumn{1}{c|}{ Sig. } \\
\cline { 2 - 4 } & \multicolumn{1}{|c|}{ B } & Std. Error & \multicolumn{1}{c|}{ Beta } & & \\
\hline (Constant) & 5,501 & 2,515 & & 2,188 & 0,031 \\
Gaya Kepemimpinan Demokratis & 0,173 & 0,067 & 0,185 & 2,592 & 0,011 \\
Motivasi Intrinsik & 0,327 & 0,098 & 0,354 & 3,327 & 0,001 \\
Disiplin Kerja & 0,334 & 0,101 & 0,366 & 3,314 & 0,001 \\
\hline
\end{tabular}

(Sumber: Data diolah, 2016)

Berdasarkan tabel diatas, persamaan regresi linear berganda yang digunakan dalam penelitian ini adalah sebagai berikut.

$$
Y=5,501+0,173 X_{1}+0,327 X_{2}+0,334 X_{3}
$$

Keterangan :

$\mathrm{Y} \quad=$ Kinerja karyawan

$\mathrm{X}_{1} \quad=$ Gaya kepemimpinan demokratis

$\mathrm{X}_{2}=$ Motivasi intrinsik

$\mathrm{X}_{3} \quad=$ Disiplin kerja

\section{Uji Kelayakan Model}

\section{Uji F}

Berikut ini merupakan tabel hasil uji F.

Tabel 6. Hasil Uji F

\begin{tabular}{|l|r|r|r|r|r|}
\hline \multicolumn{1}{|c|}{ Model } & \multicolumn{1}{|c|}{$\begin{array}{c}\text { Sum of } \\
\text { Squares }\end{array}$} & Df & $\begin{array}{r}\text { Mean } \\
\text { Square }\end{array}$ & F & Sig. \\
\hline Regression & 589,577 & 3 & 196,526 & 49,562 & 0,000 \\
Residual & 380,663 & 96 & 3,965 & & \\
Total & 970,240 & 99 & & & \\
\hline
\end{tabular}

(Sumber: Data diolah, 2016)

Berdasarkan tabel di atas, diperoleh $\mathrm{F}_{\text {hitung }}$ sebesar 49,562 yang lebih besar daripada $F_{\text {tabel }}(\alpha=5 \%)$ sebesar 2,70. Selain itu, diperoleh tingkat signifikansi sebesar 0,000 yang lebih besar daripada 0,05, sehingga dapat disimpulkan bahwa variabel gaya kepemimpinan 
demokratis, motivasi intrinsik dan disiplin kerja secara bersama-sama berpengaruh positif dan signifikan terhadap kinerja karyawan PT Pangansari Utama Food Industry, Jakarta Timur. Artinya, model yang dikembangkan dalam penelitian ini layak dan variabel yang digunakan dalam model mampu menjelaskan model yang dianalisis.

\section{Koefisien Determinasi $\left(\mathbf{R}^{2}\right)$}

Berikut ini merupakan tabel koefisien determinasi.

Tabel 7. Koefisien Determinasi

\begin{tabular}{|c|r|r|r|}
\hline $\mathbf{R}$ & $\boldsymbol{R}$ Square & $\begin{array}{c}\text { Adjusted } \boldsymbol{R} \\
\text { Square }\end{array}$ & $\begin{array}{l}\text { Std. Error of } \\
\text { the Estimate }\end{array}$ \\
\hline 0,780 & 0,608 & 0,595 & 1,991 \\
\hline
\end{tabular}

(Sumber: Data diolah, 2016)

Berdasarkan tabel di atas, nilai $\mathrm{R}^{2}$ sebesar 0,608 menunjukkan bahwa gaya kepemimpinan demokratis, motivasi intrinsik dan disiplin kerja memberikan kontribusi sebesar 60,8\% dalam menjelaskan kinerja karyawan PT Pangansari Utama Food Industry, Jakarta Timur, sedangkan 39,2\% sisanya dijelaskan oleh variabel lain yang tidak dianalisis dalam penelitian ini.

\section{Pengujian Hipotesis (Uji T)}

Berikut ini merupakan tabel hasil pengujian hipotesis.

Tabel 8. Hasil Uji T

\begin{tabular}{|l|c|c|c|l|}
\hline \multicolumn{1}{|c|}{ Variabel } & t & Sig. & $\boldsymbol{\alpha}$ & Keterangan \\
\hline Gaya Kepemimpinan Demokratis & 2,592 & 0,011 & 0,05 & Positif dan signifikan \\
Motivasi Intrinsik & 3,327 & 0,001 & 0,05 & Positif dan signifikan \\
Disiplin Kerja & 3,314 & 0,001 & 0,05 & Positif dan signifikan \\
\hline
\end{tabular}

(Sumber: Data diolah, 2016)

Hasil pengujian hipotesis di atas dapat diuraikan sebagai berikut.

1. Gaya kepemimpinan demokratis mempunyai $t_{\text {hitung }}$ sebesar 2,592 dengan nilai signifikan sebesar $0,011<0,05$, sehingga $\mathrm{H}_{0}$ ditolak dan Ha diterima. Hal tersebut menunjukkan bahwa gaya kepemimpinan demokratis berpengaruh positif dan signifikan terhadap kinerja karyawan PT Pangansari Utama Food Industry, Jakarta Timur.

2. Motivasi intrinsik mempunyai $t_{\text {hitung }}$ sebesar 3,327 dengan nilai signifikan sebesar $0,001<$ 0,05, sehingga $\mathrm{H}_{0}$ ditolak dan Ha diterima. Hal tersebut menunjukkan bahwa motivasi intrinsik berpengaruh positif dan signifikan terhadap kinerja karyawan PT Pangansari Utama Food Industry, Jakarta Timur. 
3. Disiplin kerja mempunyai $t_{\text {hitung }}$ sebesar 3,314 dengan nilai signifikan sebesar 0,001 < 0,05, sehingga $\mathrm{H}_{0}$ ditolak dan $\mathrm{Ha}$ diterima. Hal tersebut menunjukkan bahwa disiplin kerja berpengaruh positif dan signifikan terhadap kinerja karyawan PT Pangansari Utama Food Industry, Jakarta Timur.

\section{Pembahasan}

\section{Pengaruh Gaya Kepemimpinan Demokratis terhadap Kinerja Karyawan}

Berdasarkan hasil penelitian, dapat diketahui bahwa gaya kepemimpinan demokratis berpengaruh positif dan signifikan terhadap kinerja karyawan PT Pangansari Utama Food Industry, Jakarta Timur. Hal tersebut menunjukkan bahwa semakin baik gaya kepemimpinan demokratis yang diterapkan pada PT Pangansari Utama Food Industry, maka semakin baik pula kinerja karyawannya. Hasil penelitian ini sesuai dengan hasil penelitian yang dilakukan oleh Mardiana (2014) serta Yugusna, dkk. (2016) yang menunjukkan bahwa gaya kepemimpinan demokratis berpengaruh positif dan signifikan terhadap kinerja karyawan.

Perilaku pemimpin yang demokratis cenderung mendorong para karyawannya untuk menumbuhkan dan mengembangkan daya inovasi dan kreativitasnya, sehingga dapat meningkatkan kinerja karyawan di bawah pimpinannya (Siagian, 2010). Menurut Rivai (2011), gaya kepemimpinan demokratis ditandai dengan adanya suatu struktur yang pengembangannya menggunakan pendekatan pengambilan keputusan yang kooperatif. Hal ini membuat karyawan merasa dilibatkan oleh pimpinan, sehingga karyawan tersebut terdorong untuk melaksanakan tugas dan pekerjaannya dengan baik. Akibatnya, karyawan tersebut akan mencapai kinerja yang baik. Hal tersebut menunjukkan bahwa gaya kepemimpinan demokratis dapat berpengaruh positif terhadap kinerja karyawan.

\section{Pengaruh Motivasi Intrinsik terhadap Kinerja Karyawan}

Berdasarkan hasil penelitian, dapat diketahui bahwa motivasi intrinsik berpengaruh positif dan signifikan terhadap kinerja karyawan PT Pangansari Utama Food Industry, Jakarta Timur. Hal tersebut menunjukkan bahwa semakin kuat motivasi intrinsik yang dimiliki oleh karyawan PT Pangansari Utama Food Industry, maka semakin baik kinerja dari karyawan tersebut. Motivasi intrinsik yang dimaksud disini adalah motivasi karyawan untuk melaksanakan tugas dan pekerjaannya dengan baik.

Hasil penelitian ini sesuai dengan hasil penelitian yang dilakukan oleh Suwarno (2014) dan Prahiawan dan Simbolon (2014) yang menunjukkan bahwa motivasi intrinsik berpengaruh positif dan signifikan terhadap kinerja karyawan. Hal tersebut dikarenakan 
Semakin kuat motivasi intrinsik di dalam diri seorang karyawan, maka semakin kuat pula keinginan karyawan tersebut untuk melaksanakan tugas dan pekerjaannya dengan baik, sehingga semakin terdorong perilaku karyawan tersebut untuk diarahkan sesuai dengan standar kinerja dan tujuan yang telah ditetapkan oleh perusahaan. Hal tersebut pada akhirnya akan meningkatkan kinerja karyawan tersebut.

\section{Pengaruh Disiplin Kerja terhadap Kinerja Karyawan}

Berdasarkan hasil penelitian, dapat diketahui bahwa disiplin kerja berpengaruh positif dan signifikan terhadap kinerja karyawan PT Pangansari Utama Food Industry, Jakarta Timur. Hal tersebut menunjukkan bahwa semakin tinggi tingkat disiplin kerja pada PT Pangansari Utama Food Industry, maka semakin tinggi pula kinerja karyawannya. Hasil penelitian ini sesuai dengan hasil penelitian yang dilakukan oleh Yudiningsih, dkk. (2016) serta Pangarso dan Susanti (2016) yang menunjukkan bahwa disiplin kerja berpengaruh positif dan signifikan terhadap kinerja karyawan.

Menurut Robbins (2006), disiplin kerja yang tinggi diindikasikan dengan adanya rasa tanggung jawab yang tinggi dalam diri karyawan terhadap tugas-tugas yang dibebankan kepadanya. Artinya, semakin tinggi tingkat disiplin kerja seorang karyawan, maka semakin tinggi pula rasa tanggung jawab di dalam diri karyawan tersebut terhadap tugas-tugas yang dibebankan kepadanya, sehingga semakin besar upaya yang dilakukan oleh karyawan tersebut untuk melaksanakan tugas dan pekerjaannya dengan baik. Hal ini pada akhirnya akan meningkatkan kinerja karyawan tersebut.

\section{KESIMPULAN DAN SARAN}

\section{Kesimpulan}

Berdasarkan hasil penelitian yang telah diuraikan sebelumnya, dapat disimpulkan bahwa gaya kepemimpinan demokratis, motivasi intrinsik dan disiplin kerja secara parsial berpengaruh positif dan signifikan terhadap kinerja karyawan PT Pangansari Utama Food Industry, Jakarta Timur.

\section{Saran}

Berdasarkan hasil penelitian dan kesimpulan yang telah dikemukakan, perusahaan perlu mempertahankan dan meningkatkan efektivitas penerapan gaya kepemimpinan demokratis. Selain itu, perusahaan juga perlu memperhatikan motivasi intrinsik dan disiplin kerja karyawannya. Dalam rangka meningkatkan disiplin kerja karyawan, perusahaan dapat 
menetapkan sistem reward dan punishment yang ketat dalam kegiatan operasionalnya seharihari. Hal-hal tersebut dilakukan agar perusahaan dapat senantiasa mempertahankan dan meningkatkan kinerja karyawannya.

\section{DAFTAR PUSTAKA}

Gunarsa, S. D. 2008. Psikologi Perawatan. Gunung Mulia. Jakarta.

Hasibuan, M. S. P. 2012. Manajemen Sumber Daya Manusia. Edisi Revisi. PT. Bumi Aksara. Jakarta.

Mangkunegara, A.P. 2011. Manajemen Sumber Daya Manusia Perusahaan. PT Remaja Rosdakarya. Bandung.

Mardiana. 2014. Pengaruh Gaya Kepemimpinan Demokratis terhadap Kinerja Pegawai pada Kantor Sekretariat Daerah Kota Samarinda. Ejournal Ilmu Pemerintahan. 2(1):18021816.

Pangarso, A. dan P.I. Susanti. 2016. Pengaruh Disiplin Kerja terhadap Kinerja Pegawai di Biro Pelayanan Sosial Dasar Sekretariat Daerah Provinsi Jawa Barat. Jurnal Manajemen Teori dan Terapan. 9(2): 145-160.

Prahiawan, W. dan N. Simbolon. 2014. Pengaruh Motivasi Intrinsik dan Lingkungan Kerja terhadap Kinerja Karyawan pada PT Intimas Lestari Nusantara. Jurnal Ekonomi. 5(1): $35-41$.

Putra, A. K. dan A. Frianto. 2013. Pengaruh Motivasi Intrinsik dan Motivasi Ekstrinsik terhadap Kepuasan Kerja. Jurnal Ilmu Manajemen. 1(1): 377-387.

Rivai, V. 2011. Manajemen Sumber Daya Manusia Untuk Perusahaan Dari Teori Ke Praktek. PT. Raja Grafindo Persada. Jakarta.

Robbins, S. P. 2006. Organizational Behavior. Sixteenth Edition. Global Edition. Terjemahan B. Molan. 2009. Perilaku Organisasi. Edisi 16. Salemba Empat. Jakarta.

Sardiman, A.M. 2007. Interaksi dan Motivasi Belajar Mengajar. Raja Grafindo Persada. Jakarta.

Sedarmayanti. 2011. Tata Kerja dan Produktivitas Kerja. Mandar Maju. Bandung.

Siagian, S. P. 2010. Manajemen Sumber Daya Manusia. Bumi Aksara. Jakarta.

Sutarto. 2006. Dasar-Dasar Kepemimpinan Administrasi. Gadjah Mada Universitty Press. Yogyakarta.

Suwarno, T. H. 2014. Pengaruh Motivasi Intrinsik dan Kemampuan Kinerja Karyawan. Jurnal Ilmu Manajemen. 2(3): 928-940.

Wibowo. 2011. Manajemen Kinerja. Edisi ketiga. Rajawali Pers. Jakarta. 
Yudiningsih, N. M. D., F. Yudiaatmaja., N. N. Yulianthini. 2016. Pengaruh Lingkungan Kerja dan Disiplin Kerja terhadap Kinerja Pegawai . Ejournal Bisma Universitas Pendidikan Ganesha Jurusan Manajemen. 4:1-7.

Yugusna, I., A. Fathoni dan A.T. Haryono. 2016. Pengaruh Gaya Kepemimpinan Demokratis dan Lingkungan Kerja terhadap Kinerja dan Kedisiplinan Karyawan. Journal of Management. 2(2). 